\title{
Requirements for privatization of Iran pro league football clubs
}

\author{
Mehrali Hemati-Nejad, Hamid-Reza Goharrostami, Seyyed Sajjad Hosseini \\ Faculty of Physical Education and Sport Sciences, University of Guilan, Rasht, Iran
}

\begin{abstract}
Purpose:

The purpose of this research was to determine the requirements for privatization of Iran Pro League (IPL) football clubs.

Material: $\quad$ A questionnaire was developed and distributed among a sample of IPL coaches, executives (senior executives from the Ministry of Youth Affairs and Sports and the Privatization Organization), and faculty members (public and private universities). Descriptive statistics and Kruskal-Wallis test were used for data analysis. Besides, AHP was used in Expert Choice software to weight and rank the items.

Results: $\quad$ The results showed that the most important factors were fighting corruption and rent-seeking during and after biddings (political), improving public perception of privatization of football clubs (sociocultural), increasing revenues from ticket sales (economic), transparency in laws regarding football club privatization (legal), and the changing structure and role of the government from exclusive ownership to oversight (structural).

Conclusions: Given the results of this research, the most important requirements for privatization of IPL football clubs include offering television broadcast rights, advertisement rights, and ticket sale rights to the clubs, and these and other factors discussed earlier are likely to accelerate privatization of football clubs.

Keywords: privatization, football clubs, requirements, coaches.
\end{abstract}

\section{Introduction}

One of the main challenges of governments is finding optimal ways of handling economic affairs. A major concern, especially in less developed countries, is the large size of the government and the extent to which it interferes in unnecessary activities. In most cases, this leads to higher costs, establishment of parallel institutions, and poor management, thus limiting economic activities by the people, reducing efficiency and productivity significantly, and disrupting the economic balance of the country [20]. Privatization is one of the most effective solutions commonly proposed by politicians and economics. Privatization of businesses in Iran was approved and initiated in 1991 based on the principles of the Iranian Constitution and the First Economic, Social, and Cultural Development Plan [27].

This process continued during the Second and Third Development Plans and was intensified during the Fourth Development Plan. In the sports sector, especially in football, there was a long-lasting assumption that clubs must be directly administered or indirectly supported by the public sector. However, the result was the failure of the government to run the costly business of sport clubs and provide quality services under a public economic system. Thus, the potential for the private sector purchasing and running clubs increased.

According to existing laws, government institutions must privatize the management of sport clubs, venues, and equipment [2]. Moreover, Iran's poor sports infrastructure and lack of funds cannot respond to the growing needs of the society, further highlighting the importance of participation and investment by the private sector in sports development. Statistics show that despite the shortcoming of the government in developing sports infrastructure, the private sector has a low share in the ownership of indoor

\footnotetext{
(c) Mehrali Hemati-Nejad, Hamid-Reza Goharrostami,

Seyyed Sajjad Hosseini, 2017
}

doi:10.15561/20755279.2017.0106 and outdoor sports facilities, amounting to $19.36 \%$ and 9.07\% respectively [18]. Despite the propensity of the private sector to build sports facilities and develop sports infrastructure, it has been unable to invest in these areas for a variety of reasons, including high costs, insufficient support by the government, and lack of incentives and security for private-sector investment [1].

Data from other countries suggest a significant increase in private-sector participation in administering sports clubs and developing sports facilities. From 1995 to 2003 , $\$ 4.70$ billion was spent on building 24 new major arenas in the U.S. and Canada, of which only 39\% was contributed from public sources. In a little over a decade, arena financing moved from being almost exclusively publicly subsidized to being primarily financed by franchise owners. The average cost of arenas in this most recent era was over $\$ 222$ million. Thus, 39\% of the average cost is $\$ 86$ million, which in real dollar terms exceeds the contribution government was making in the early 1969-1984 eras when it was paying $100 \%$ of the cost [5].

The volume of private sector participation indicates accurate and strategic planning by governments and their success in sports industry privatization. However, certain requirements must be considered and met in moving from government monopoly to privatization. Various studies have examined the strengths, weaknesses, opportunities, and threats in privatization of sports clubs, especially regarding football. Some studies have identified government support and legal power to develop sports clubs [19] and successful attraction of private investors [21] as the strengths of private sector participation, while some others have noted lack of government support and incentives [22] and the high cost of using private sports complexes [15] as the weaknesses of privatization of sports industry. High risk of investing in the sports sector [15], economic instability [25] are shown to be some of the major threats for private-sector participation and sports 
development. On the other hand, major opportunities include the potential for private-sector investment [21], political stability [22], and the increasing popularity of sports [14].

In one study of privatization in Iran, Korchian (2008) showed that privatization through competitive bidding is the best way of privatizing the sports industry and argued that this process is affected by a variety of institutional and organizational, socioeconomic, legal, and political factors [14]. Therefore, privatization in Iran is likely to expand only if there are no political barriers to its implementation and if it is in the economic interest of the government and profitable for investors. Some studies have also identified various environmental imperatives of privatization of the sports industry.

There is obviously a need to extensive research on privatization of sports as it is one of the hottest topics in Iran's academia. Most studies carried out so far have focused on the sports industry as a whole, and to our knowledge there is no research on requirements for privatization of Iran Pro League football clubs. Therefore, the present research aims to describe the current condition of privatization of football teams, identify the factors that affect this process, and discuss the possible outcomes of privatizing the most popular sport in Iran.

The information includes the results of studies conducted in some other countries as well, since sports industry in these countries has undergone privatization and their experience will provide valuable insights and guidelines for research stakeholders. The results are expected to solve some of the problems the country faces in privatizing sports, especially football clubs.

\section{Material and methods}

Participants. The population consisted of the executives of the Ministry of Sports, managers and coaches of football clubs in Iran Pro League (IPL), and sports management experts. 56 individuals were selected from the population using purposive sampling and completed the questionnaire.

Research Design. A questionnaire was developed in two parts:

1. Demographic data (i.e. age, education, job, sporting experience, sport management experience)

2. Privatization Scale.

To construct the scale, first the relevant theories were studied and the literature was reviewed to extract key issues pertaining to requirements for privatization. Then, interviews were held with experts in the field of sports management with administrative experience, officials from Iran's Privatization Organization, and members of Commission 44 of the Parliament. The questionnaire was then developed based on the views of experts about the requirements for privatization and was completed by the participants.

Statistical Analysis. Descriptive statistics were used for data analysis and the mean and standard deviation of the data were recorded. Moreover, the homogeneity and normal distribution of the data were examined using Levene's test and Kolmogorov-Smirnov test. The results showed that despite their homogeneity of variance ( $p$ $=0.072)$, the data were not normally distributed $(\mathrm{p}=$ 0.01). Therefore, non-parametric tests were used for data analysis.

Binomial test was used to examine questionnaire items and identify the requirements for privatization of IPL football clubs. The items were rated on a 5-point Likert scale, with the rating of 3 being the threshold. That is, items with ratings equal or greater than 3 were the requirements for privatization in IPL. The analytical hierarchy process (AHP) was used to rank the requirements and Kruskal-Wallis one-way analysis of variance was used to examine differences between respondent groups. All the statistical analyses were performed in SPSS 22 at the 0.05 significance level.

\section{Results}

Table 1 provides the demographic data of the respondents (i.e. age, education, job, sporting experience, sport management experience).

The results of binomial test of privatization requirements showed that the observed p-value was greater than the expected p-value for three of the four structural factors and that these items were significant requirements for privatization in IPL:

- Changing structure and role of the government from exclusive ownership to oversight without any interference in club affairs

- Supporting private companies that volunteer to purchase IPL football clubs

- Reforming the structure of volunteer companies The results showed that 'establishing intermediaries between companies and the Ministry of Sports' was not a significant requirement for privatization in IPL, as the observed p-value was less than the expected p-value (Table 2).

In terms of legal factors, the results of binomial test indicated that the observed p-value was greater than the expected p-value for three of the four factors and these items were significant requirements for privatization in IPL:

- Transparency of laws pertaining to privatization of football clubs

- Economic liberalization, including adoption of competitive economy and pricing reform

- Adequate legal support for investors.

However, 'new legislation and reform of existing laws pertaining to club ownership' had a p-value less than the expected value and thus the null hypothesis was accepted (Table 2).

The results of binomial test showed that the observed p-value was greater than the expected p-value for three of the four economic factors and that these items were significant privatization requirements:

- Increasing club revenues from ticket sales

- Increasing revenues from television broadcast rights

- Increasing stability and security for the private sector 
Table 1. Demographics data

\begin{tabular}{|c|c|c|c|c|c|}
\hline Groups & Position & $\begin{array}{l}\text { Academic } \\
\text { Degree }\end{array}$ & Frequency & Percentage & $\begin{array}{l}\text { Cumulative } \\
\text { Percentage }\end{array}$ \\
\hline \multirow{12}{*}{ Executives } & \multirow{3}{*}{$\begin{array}{l}\text { Parliament } \\
\text { Research Center }\end{array}$} & $\mathrm{PhD}$ & 1 & 1.78 & 1.78 \\
\hline & & MSc & 2 & 3.57 & 5.35 \\
\hline & & $\mathrm{BSC}$ & 3 & 5.35 & 10.70 \\
\hline & \multirow{3}{*}{$\begin{array}{l}\text { Privatization } \\
\text { Organization }\end{array}$} & $\mathrm{PhD}$ & 1 & 1.78 & 12.48 \\
\hline & & $\mathrm{MSc}$ & 4 & 7.14 & 19.62 \\
\hline & & $\mathrm{BSC}$ & 3 & 5.35 & 24.97 \\
\hline & \multirow{3}{*}{$\begin{array}{l}\text { Committee } 44 \\
\text { Member }\end{array}$} & $\mathrm{PhD}$ & 2 & 3.57 & 28.54 \\
\hline & & MSc & 3 & 5.35 & 33.89 \\
\hline & & $\mathrm{BSC}$ & 1 & 1.78 & 35.67 \\
\hline & \multirow{3}{*}{$\begin{array}{l}\text { Football Club } \\
\text { Managers }\end{array}$} & $\mathrm{PhD}$ & 1 & 1.78 & 37.45 \\
\hline & & MSc & 5 & 8.92 & 46.37 \\
\hline & & BSC & 6 & 10.71 & 57.08 \\
\hline \multirow{3}{*}{ Coaches } & \multirow{3}{*}{ IPL Football Coaches } & $\mathrm{PhD}$ & 1 & 1.78 & 58.86 \\
\hline & & $\mathrm{MSc}$ & 5 & 8.92 & 67.78 \\
\hline & & BSc & 4 & 7.14 & 74.92 \\
\hline $\begin{array}{l}\text { Faculty } \\
\text { Members }\end{array}$ & $\begin{array}{l}\text { Sports Management } \\
\text { Professors }\end{array}$ & $\mathrm{PhD}$ & $\begin{array}{l}14 \\
N=56\end{array}$ & 25.00 & 100 \\
\hline
\end{tabular}

in the business environment.

However, the results showed that 'empowering the private sector' was not a significant privatization requirement and the null hypothesis was accepted (Table 2).

As for sociocultural factors, the results of binomial test indicated that the observed p-value was greater than the expected p-value for two of the four factors and that these items were significant privatization requirements:

- Improving public perception of privatization of football clubs

- $\quad$ Promoting the culture of supporting football clubs by purchasing tickets and club promotional items.

However, for two sociocultural factors, i.e. 'promoting the purchase of football club shares' and 'promoting the culture of profitability and competition in IPL', the observed p-value was less than the expected p-value and thus these factors were not significant privatization requirements (Table 2).

The results of binomial test showed that for two of the five political factors the observed p-value was higher than the expected p-value and that these items were significant privatization requirements:

- Fighting corruption and rent-seeking during and after IPL biddings

- Serious attempts by the government and the parliament to develop and optimize sports infrastructure.

However, for the rest of the political factors, i.e. 'separating decision-making and decision-taking institutions', 'protecting the property rights of companies or individuals that win the bids', and 'creating a platform and a system that encourages the establishment of new football clubs', the observed p-value was less than the expected p-value and the null hypothesis was accepted (Table 2).

The results of Freidman test showed that some items are more important than the others (Table 3).

The results of Kruskal-Wallis one-way ANOVA showed that the mean ranks of privatization requirements are not equal and that some requirements are more important than the others. Therefore, Friedman test was used to rank these factors.

Based on the results of Friedman, the most important privatization requirements were the following: increasing club revenues from ticket sales, increasing revenues from television broadcast rights, and promoting the culture of supporting football clubs by purchasing tickets and promotional items. 'Fighting corruption and rentseeking during and after IPL biddings', 'transparency of laws pertaining to privatization of football clubs', and 'serious attempts by the government and the parliament to develop and optimize sports infrastructure' were other major privatization requirements. However, factors such as 'creating a platform and a system that encourages the establishment of new football clubs', 'protecting the property rights of companies or individuals that win the bids', and 'separating decision-making and decisiontaking institutions' were the least important factors. 
Table 2. The results of binomial test

\begin{tabular}{|c|c|c|c|c|c|}
\hline Requirements & Items & $\begin{array}{l}\text { Observed } \\
\text { P-value }\end{array}$ & $\begin{array}{l}\text { Expected } \\
\text { P-value }\end{array}$ & Sig. & Result \\
\hline \multirow{4}{*}{ Structural } & $\begin{array}{l}\text { Changing structure and role of the government } \\
\text { from exclusive ownership to oversight without any } \\
\text { interference in club affairs }\end{array}$ & 0.53 & 0.50 & 0.01 & Significant \\
\hline & $\begin{array}{l}\text { Supporting private companies that volunteer to } \\
\text { purchase IPL football clubs }\end{array}$ & 0.75 & 0.50 & 0.01 & Significant \\
\hline & Reforming the structure of volunteer companies & 0.83 & 0.50 & 0.02 & Significant \\
\hline & $\begin{array}{l}\text { Establishing intermediaries between companies and } \\
\text { the Ministry of Sports }\end{array}$ & 0.46 & 0.50 & 0.61 & $\begin{array}{l}\text { Not } \\
\text { Significant }\end{array}$ \\
\hline \multirow{4}{*}{ Legal } & $\begin{array}{l}\text { Transparency of laws pertaining to privatization of } \\
\text { football clubs }\end{array}$ & 0.65 & 0.50 & 0.01 & Significant \\
\hline & $\begin{array}{l}\text { New legislation and reform of existing laws } \\
\text { pertaining to club ownership }\end{array}$ & 0.37 & 0.50 & 0.07 & $\begin{array}{l}\text { Not } \\
\text { Significant }\end{array}$ \\
\hline & $\begin{array}{l}\text { Economic liberalization, including adoption of } \\
\text { competitive economy and pricing reform }\end{array}$ & 0.83 & 0.50 & 0.01 & Significant \\
\hline & Adequate legal support for investors & 0.62 & 0.50 & 0.03 & Significant \\
\hline \multirow{4}{*}{ Economic } & Empowering the private sector & 0.24 & 0.50 & 0.32 & $\begin{array}{l}\text { Not } \\
\text { Significant }\end{array}$ \\
\hline & Increasing club revenues from ticket sales & 0.67 & 0.50 & 0.01 & Significant \\
\hline & Increasing revenues from television broadcast rights & 0.61 & 0.50 & 0.01 & Significant \\
\hline & $\begin{array}{l}\text { Increasing stability and security for the private } \\
\text { sector in the business environment }\end{array}$ & 0.65 & 0.50 & 0.01 & Significant \\
\hline \multirow{4}{*}{ Sociocultural } & $\begin{array}{l}\text { Improving public perception of privatization of } \\
\text { football clubs }\end{array}$ & 0.73 & 0.50 & 0.02 & Significant \\
\hline & Promoting the purchase of football club shares & 0.43 & 0.50 & 0.08 & $\begin{array}{l}\text { Not } \\
\text { Significant }\end{array}$ \\
\hline & $\begin{array}{l}\text { Promoting the culture of profitability and } \\
\text { competition in IPL }\end{array}$ & 0.33 & 0.50 & 0.13 & $\begin{array}{l}\text { Not } \\
\text { Significant }\end{array}$ \\
\hline & $\begin{array}{l}\text { Promoting the culture of supporting football clubs } \\
\text { by purchasing tickets and promotional items }\end{array}$ & 0.67 & 0.50 & 0.01 & Significant \\
\hline \multirow{5}{*}{ Political } & $\begin{array}{l}\text { Separating decision-making and decision-taking } \\
\text { institutions }\end{array}$ & 0.38 & 0.50 & 0.54 & $\begin{array}{l}\text { Not } \\
\text { Significant }\end{array}$ \\
\hline & $\begin{array}{l}\text { Protecting the property rights of companies or } \\
\text { individuals that win the bids }\end{array}$ & 0.43 & 0.50 & 0.32 & $\begin{array}{l}\text { Not } \\
\text { Significant }\end{array}$ \\
\hline & $\begin{array}{l}\text { Fighting corruption and rent-seeking during and } \\
\text { after IPL biddings }\end{array}$ & 0.65 & 0.50 & 0.01 & Significant \\
\hline & $\begin{array}{l}\text { Serious attempts by the government and the } \\
\text { parliament to develop and optimize sports } \\
\text { infrastructure }\end{array}$ & 0.64 & 0.50 & 0.01 & Significant \\
\hline & $\begin{array}{l}\text { Creating a platform and a system that encourages } \\
\text { the establishment of new football clubs }\end{array}$ & 0.42 & 0.50 & 0.07 & $\begin{array}{l}\text { Not } \\
\text { Significant }\end{array}$ \\
\hline
\end{tabular}

Table 3. Kruskal-Wallis one-way analysis of variance

\begin{tabular}{lllll}
\hline Null Hypothesis & Sig. & df & Observed Chi-squared & Result \\
\hline Privatization requirements have equal mean ranks & 0.01 & 20 & 71.34 & Rejected \\
\hline
\end{tabular}

\section{Discussion}

The purpose of this research was to identify and rank the requirements for privatization of football clubs in Iran Pro League (IPL). A questionnaire was developed with a variety of political, sociocultural, economic, legal, and structural items and was distributed among a sample of coaches, executives (senior executives from the Ministry of Youth Affairs and Sports and the Privatization
Organization), and faculty members (public and private universities).

The results showed that among political requirements for privatization, 'fighting corruption and rent-seeking during and after IPL biddings' and 'serious attempts by the government and the parliament to develop and optimize sports infrastructure' were the most important factors, while 'creating a platform and a system that encourages 
Table 4. The results of Freidman test for ranking privatization requirements by their importance

\begin{tabular}{|c|c|c|c|}
\hline Item & Mean & $\begin{array}{l}\text { Mean } \\
\text { Rank }\end{array}$ & Rank \\
\hline $\begin{array}{l}\text { Changing structure and role of the government from exclusive ownership to oversight } \\
\text { without any interference in club affairs }\end{array}$ & 3.93 & 3.59 & 8 \\
\hline Supporting private companies that volunteer to purchase IPL football clubs & 4.08 & 7.88 & 7 \\
\hline Reforming the structure of volunteer companies & 3.25 & 6.06 & 13 \\
\hline Establishing intermediaries between companies and the Ministry of Sports & 2.93 & 5.36 & 14 \\
\hline Transparency of laws pertaining to privatization of football clubs & 4.38 & 8.66 & 5 \\
\hline New legislation and reform of existing laws pertaining to club ownership & 2.83 & 5.12 & 15 \\
\hline Economic liberalization, including adoption of competitive economy and pricing reform & 3.51 & 6.13 & 12 \\
\hline Adequate legal support for investors & 3.75 & 7.24 & 11 \\
\hline Empowering the private sector & 2.73 & 4.88 & 16 \\
\hline Increasing club revenues from ticket sales & 4.72 & 9.67 & 1 \\
\hline Increasing revenues from television broadcast rights & 4.69 & 9.61 & 2 \\
\hline Increasing stability and security for the private sector in the business environment & 3.83 & 7.31 & 10 \\
\hline Improving public perception of privatization of football clubs & 3.86 & 7.43 & 9 \\
\hline Promoting the purchase of football club shares & 2.56 & 4.53 & 17 \\
\hline Promoting the culture of profitability and competition in IPL & 2.39 & 4.47 & 18 \\
\hline $\begin{array}{l}\text { Promoting the culture of supporting football clubs by purchasing tickets and promotional } \\
\text { items }\end{array}$ & 4.46 & 9.52 & 3 \\
\hline Separating decision-making and decision-taking institutions & 2.17 & 4.22 & 19 \\
\hline Protecting the property rights of companies or individuals that win the bids & 1.89 & 4.11 & 20 \\
\hline Fighting corruption and rent-seeking during and after IPL biddings & 4.41 & 8.69 & 4 \\
\hline $\begin{array}{l}\text { Serious attempts by the government and the parliament to develop and optimize sports } \\
\text { infrastructure }\end{array}$ & 4.14 & 8.23 & 6 \\
\hline $\begin{array}{l}\text { Creating a platform and a system that encourages the establishment of new football } \\
\text { clubs }\end{array}$ & 1.74 & 4.06 & 21 \\
\hline
\end{tabular}

the establishment of new football clubs', 'protecting the property rights of companies or individuals that win the bids', and 'separating decision-making and decisiontaking institutions' were less important.

Among sociocultural factors, 'improving public perception of privatization of football clubs' and 'promoting the culture of supporting football clubs by purchasing tickets and promotional items' were more important than 'promoting the purchase of football club shares' and 'promoting the culture of profitability and competition in IPL'. Among economic factors, 'increasing club revenues from ticket sales', 'increasing revenues from television broadcast rights', 'increasing stability and security for the private sector in the business environment' were more important than 'empowering the private sector'. Among legal factors, 'transparency of laws pertaining to privatization of football clubs', 'economic liberalization, including adoption of competitive economy and pricing reform', and 'adequate legal support for investors' were more important than 'new legislation and reform of existing laws pertaining to club ownership'.

Finally, among structural factors, 'changing structure and role of the government from exclusive ownership to oversight without any interference in club affairs', 'supporting private companies that volunteer to purchase IPL football clubs', 'reforming the structure of volunteer companies' were more important than 'establishing intermediaries between companies and the Ministry of Sports'.

In ranking the privatization requirements by importance, 'increasing club revenues from ticket sales', 'increasing revenues from television broadcast rights', and 'promoting the culture of supporting football clubs by purchasing tickets and promotional items' were at the most important factors overall. This finding is consistent with the results of Rezayi et al. (2015) and Gharekhani et al. (2011). Rezayi et al. (2015) identified the interaction between people and television and purchase of promotional sports items as key factors in commercialization and ultimately privatization of football clubs [23, 10, 22]. Gharekhani et al. (2011) examined the most important economic barriers to privatization of football clubs in Iran and found that low ticket sale revenue and lack of payments for television broadcast rights and virtual advertising were major barriers to privatization [10].

Moreover, the results showed that 'fighting corruption and rent-seeking during and after IPL biddings', 'transparency of laws pertaining to privatization of football clubs', and 'serious attempts by the government and the parliament to develop and optimize sports infrastructure' were major privatization requirements. This is also consistent with past research findings. For instance, Sameti (2010) conducted a case study for reducing the economic activities of Iranian government and found 
that the sociocultural and political characteristics of any economy affect the speed of transition from public to private sector, and that the process of privatization has been very quick in societies with a history of democracy and with a proper legal foundation [24]. That is because in developed economies with effective legal systems, the responsibilities of agents are well-defined and all the legal aspects of transition are clear [24].

Korchian (2008) argued that there is the legal basis for privatization in Iran, but laws are excessively complex and are not properly implemented, which affect the transfer of capital from public to private sector [14]. Repeated reform in tax laws were also considered a major factor causing uncertainty in private-sector investment. Marduki (2006) showed that corruption and rent-seeking discourage investment in the private sector and contribute to uncertainty in the business environment [17]. Unless there is a serious drive for fighting corruption and rentseeking in the government, the private sector will not be able to compete with the public sector and will head toward negative returns, thus deterring private companies from participating in the transfer from the public sector to the private sector.

Supporting private companies that volunteer to purchase IPL football clubs', 'changing structure and role of the government from exclusive ownership to oversight without any interference in club affairs', and 'improving public perception of privatization of football clubs' were next in the ranking and important privatization requirements. This is also consistent with the results of past research. One of the primary principles for transferring the administration of certain public organizations to the private sector is to hand them over to powerful organizations to prevent the failure of privatization in early stages.

Iran's Privatization Organization must support and incentivize private companies to purchase and run public companies and some government organizations (Bagherzadeh, 2002). Principle 44 of the Constitution requires a change in the role of the government from leadership to supervision over national economy and investment in the private sector (Abbasi, 2006). These requirements were highlighted in the present research in the context of privatizing football clubs. It has previously been documented that one of the main reasons for the departure of investors from Iran is opposition to capitalism by the government and a portion of the population.

As a result, incentives for private investment were suppressed by the fear of and frustration with social rejection. Public perception of privatization has been a significant disincentive for the private sector. Therefore, public attitude toward privatization must be improved and the culture of transferring power from the government to the private sector must be promoted in order to facilitate the process of privatization [2]. In this research, improving public perception of privatization of football clubs was identified as one of the key privatization requirements.

Overall, the results of the present research were consistent with past research on privatization requirements. In this research, increasing club revenues from ticket sales, increasing revenues from television broadcast rights, and promoting the culture of supporting football clubs by purchasing tickets and promotional items were found to be the most important requirements for privatization of football clubs in IPL. This was in line with the results of similar studies conducted in Iran. However, unlike previous studies, these factors were approved by sports management experts, Parliament members, Privatization Organization officials, and IPL managers and coaches, which add to the credibility of the findings. The results of this study can provide a crucial guideline for privatization of IPL clubs.

\section{Conclusion}

Based on the present findings, it can be argued that privatization of football clubs can be facilitated by giving television broadcast rights, advertisement revenues, and ticket sale revenues to the clubs, all of which are currently controlled by the government. These and other factors discussed in this research can accelerate the transfer of sports clubs from the public sector to the private sector.

\section{Conflict of interests}

The authors declare that there is no conflict of interests.

\section{References}

1. Abbasi M. Policy-making around the 44th Principle of the Constitution. Iran Parliament Research Center; 2006.

2. Azizi F. History of the 44th Principle of the Constitution and Its General Policies. Iran Parliament Research Center; 2009.

3. Bagherzadeh A. Market, Government, and Consumer Rights. Tehran: Development Publishing; 2002.

4. Barros CP. Portuguese football. Journal of Sports Economics. 2006; 7: 96-104.

5. Crompton JL, Howard DR. Financing major league facilities: Status, evolution and conflicting forces. Journal of Sport Management. 2003; 17: 156-184.

6. Danayifar H, Hassan E, Azar A. Qualitative Research Methodology in Management. Tehran: Saffar Publications; 2009.

7. Doherty A, Murray M. The strategic sponsorship process in a non-profit sport organization. Sport Marketing Quarterly: 2007; 16: 49-59.

8. Donya P. Prioritization of factors in sport club privatization. Master's Thesis, Faculty of Physical Education \& Sports Science. Isfahan University; 2009.

9. Elmi M. Commercialization of Academic Research. Trade Promotion Organization of Iran; 2009.

10.Gharekhani H, Ehsani M, Khabiri M, et al. Important barriers to privatization of Iranian football clubs. Iranian Journal of Sports Science Research. 2011; 9: 125-138.

11.Keen A. English football and its governance. All Party Parliamentary Football Group, Thales: London; 2009.

12.Kesenne S. Belgian football: A comment. Journal of Sports Economics, 2007;8: 670-674.

13.Khabiri M. Comparison of IPL football clubs to EUFA standards and selected football clubs from Japan, South 
Korea, UAE, and Turkey. Research Project, Physical Education \& Sports Science Center, Ministry of Science, Research and Technology, Iran; 2004.

14.Korchian N. A model for promotion and expansion of privatization in Iran. Iranian Journal of Scientific Research. 2008; 40: 219-258.

15.MahdaviA. Astudy of the privatization process in development of sports in Iran and ways to reinforce it. National report, Physical Education Organization: Iran; 2004.

16.Marduki B. Private Sector Economy and Industry: Past and Preset. Tehran: SAMT; 2006.

17.Nauright J, Ramfjord J. Who owns England's game? American professional sporting influences and foreign ownership in the premier League. Soccer \& Society. 2010; 11: 428-441.

18.Physical Education Organization. Detailed Plan for Physical Education and Sports Development. Tehran: SAMT; 2005.

19.Pringle JJ, Rondinelli DA. Privatization and corporate restructuring in Central Europe. Journal of East-West Business. 2008; 3: 43-61.

20.Rahimi Boroujerdi A. Privatization. Tehran: University Press; 2006.
21.Ramezani R. Economics and finance in sports: A case of football. Research Project, Iran Physical Education Organization; 2007.

22.Razavi MH. Analysis of Iran's sport privatization policy with an emphasis on championship sports. Doctoral Dissertation, Faculty of Physical Education \& Sports Science: University of Tehran; 2004.

23.Rezaei S, Ehsani M, Amiri M. An effective mechanism for commercialization of football clubs in Iran. Iranian Journal of Sports Management \& Motor Behavior. 2015; 5: 119-131.

24.Sameti M. A case study for reducing economic activities by Iranian government. Ministry of Economic Affairs and Finance: Iran; 2010.

25.Shahrabi M. Iranian football submerged in money. Iranian Journal of Football Outlook. 2009; 9: 44-46.

26.Shibata N, Kajikawa Y, Sakata I. Extracting the commercialization gap between science and technology: Case study of a solar cell. Technological Forecasting and Social Change. 2010; 77: 1147-1155.

27.Tahmasbi F. Barriers to privatization of industries in Iran. Master's Thesis, Imam Sadiq University: Tehran; 1999.

Information about the authors:

Mehrali Hemati-Nejad; http://orcid.org/0000-0001-6999-9797; ma hemati@yahoo.com; University of Guilan; Rasht, Khalij Fars highway, 5th kilo meter of Ghazvin road, Postal Code 4199613776, Iran.

Hamid-Reza Gohar-Rostami; http://orcid.org/0000-0002-6518-466X; goharrostami@gmail.com; University of Guilan; Rasht, Khalij Fars highway, 5th kilo meter of Ghazvin road, Postal Code 4199613776, Iran.

Seyyed Sajjad Hosseini; http:// orcid.org/0000-0001-6797-7842; ssajadh.abhar@gmail.com University of Guilan; Rasht, Khalij Fars highway, 5th kilo meter of Ghazvin road, Postal Code 4199613776, Iran.

Cite this article as: Mehrali Hemati-Nejad, Hamid-Reza Goharrostami, Seyyed Sajjad Hosseini. Requirements for privatization of Iran pro league football clubs. Physical education of students, 2017;1:33-39. doi:10.15561/20755279.2017.0106

The electronic version of this article is the complete one and can be found online at: http://www.sportedu.org.ua/index.php/PES/issue/archive

This is an Open Access article distributed under the terms of the Creative Commons Attribution License, which permits unrestricted use, distribution, and reproduction in any medium, provided the original work is properly cited (http://creativecommons.org/licenses/by/4.0/deed.en).

Received: 28.12.2016

Accepted: 15.01.2017; Published: 10.02.2017 